\title{
A MIXED INTERVAL TYPE-2 FUZZY BEST-WORST MACBETH APPROACH TO CHOOSE HUB AIRPORT IN DEVELOPING COUNTRIES: CASE OF IRANIAN PASSENGER AIRPORTS
}

\author{
Mahsa PISHDAR ${ }^{1}$, Fatemeh GHASEMZADEH ${ }^{2}$, Jurgita ANTUCHEVIČIENË $\dot{3}^{3^{*}}$ \\ ${ }^{1,2}$ Faculty of Management and Accounting, Allameh Tabataba'i University, Tehran, Iran \\ ${ }^{3}$ Dept of Construction Management and Real Estate, Vilnius Gediminas Technical University, Vilnius, Lithuania
}

Received 23 February 2019; revised 2 May 2019, 8 July 2019; accepted 13 July 2019

\begin{abstract}
Hub airports are the ones that model networks in which most journeys go via a few central points. Famous hub airports deliver positive social and environmental impact to the communities along with economic effects. This paper is about to investigate indicators related to hub performance excellence from various angles, considering leading hub airports performance while determining the priorities in order to help airports especially in developing countries to find the way of progress. A list of Key Performance Indicators (KPIs) is prepared from the literature, which is prioritized using Best-Worst Method (BWM). The weights of these criteria are specified via application of interval type-2 fuzzy BWM. Then using five most important criteria, MACBETH (Measuring Attractiveness by a Categorical Based Evaluation TecHnique) ranking approach is used to analyse 19 Iranian international airports and find the most appropriate one for being hub airport. The results show Kish airport with the International Civil Aviation Organization (ICAO) code "OIBK" is prior to other airports and can be chosen as the hub airport that means Iran airports holding company is suggested to focus more investments in this airport to gain fastest possible benefits of an international hub airport.
\end{abstract}

Keywords: hub airport, international airport, KPI, BWM, MACBETH, fuzzy type-2, MCDM.

\section{Notations}

AHP - analytic hierarchy process;

ANP - analytic network process;

BWM - best-worst method;

CI - compatibility index;

CR - compatibility rate;

DEA - data envelopment analysis;

DEA-AR - assurance region DEA;

DSS - decision support system;

EBITDA - earnings before interest, taxes, depreciation and amortization;

EMAS - eco-management and audit scheme;

FARE - factor relationship;

ICAO - International Civil Aviation Organization;

KPA - key performance area;

KPI - key performance indicator;

MACBETH - measuring attractiveness by a categorical based evaluation technique;

MADM - multiple attribute decision-making;

MCDM - multi-criteria decision-making;

PMS - performance measurement system;
SERVQUAL - service quality;

SMART - simple multi-attribute rating technique; WLU - work load unit.

\section{Introduction}

Nowadays, airport traffic is much more uncertain and every government has become aware of the importance of hub airport presence in their country because of its various benefits for airlines, passengers, local people and the whole country (Shojaei et al. 2018; Scholz, Von Cossel 2011). Hub airports are the ones that model networks in which most journeys go via a few central points. Airlines can run more frequent planes if the network is efficient. The excellence of the international airport to become the passenger hub and make connections to other regions in the world is the most important criteria to decrease operating costs for the aviation business (Jantachalobon, Suthikarnnarunai 2015). Besides, it should be noted that economic effects of successful hub airports have incredible role in financial gaining of the countries (Jahango-

${ }^{*}$ Corresponding author. E-mail: jurgita.antucheviciene@vgtu.lt 
shai Rezaee, Yousefi 2018; Homsombat et al. 2011). Based on "Airport Economics 2018 Report..." presented by Airports Council International (ACI), global aviation revenue is about $161.3 \$$ billion, $56 \%$ of which is gained by aeronautical services while the other share belongs to non-aeronautical and non-operating services. Revenue of Hartsfield-Jackson Atlanta International Airport as the busiest airport by passenger traffic in the whole world is about 723678 \$ for 2017 while Frankfurt hub airport for instance as the 14th global busiest airport by passenger traffic is about $2934.8 €$ million for 2017 , which is still enormous (ACI 2018).

Global trend in air passenger movements is changing and competition between airports and airlines is getting fiercer in a way that they themselves challenge the quality of their non-financial performance too (Mirković, Tošić 2017). Because of growing air travels, modern airports are more and more looking like cities considering infrastructure, interior and exterior design and the overall resources are required to help travellers to have pleasure time (Milbredt et al. 2017; Thomas-Emberson 2007). Airport terminals today even include welfare facilities such as movie theatres, hotels and yoga classes. People can shop, have fun or organize their work meetings at the conference halls while waiting to get on the next flight. However, Services like these make the ecological footprint of the aviation industry to go higher too. That is why if airports want to survive and gain brand image or enhance their networks with other airports, they should be brought in with the current process of becoming sustainable (Mirković, Tošić 2017).

Famous hub airports deliver positive social and environmental impact to the communities along with economic effects. Airports know that investing in renewable energy sources has a positive impact on their financial status (Peneda et al. 2011). For instance, Middle Eastern airports are now capable of running a large amount of potential flight connections between other origins with optimum travel times and least interruptions. Emirates, Doha, Abu Dhabi and Qatar Airways have entered the air travel market and challenges have leaked in the way of European and American airports such as Frankfurt Airport, although Frankfurt strengthens its position as super-hubs (Piltz et al. 2018). Frankfurt Airport is one of the world's busiest international gateways, known as the 360-degree hub. It has a strongly integrated network spanning all continents, outmanoeuvring many European competitors, which focus only on particular regions. Its terminal 2 offers direct road links to the airport, the autobahn system and even rail networks while the baggage sorting and conveyor system enables the airport to offer transfer times of less than $45 \mathrm{~min}$. Service companies, hotels, meeting and conference facilities, catering, retail, and entertainment facilities are all available. Frankfurt Airport has made substantial headway in developing its environmental leadership in the aviation business too. European EMAS is under attention of this airport allowing compa- nies to evaluate and improve their environmental performance (Schulte 2009). Similar characteristics have made Singapore Airport one of the bests too. Luggage carts are widely and freely available while passengers can gain their needed information from special kiosks in every terminal section. Staffs are well trained and truly guide passengers. However, printed map can be used too. Wi-Fi is free throughout the airport. There are also some cinemas, fitness and massage centres, children's playgrounds, many shops and food and beverage outlets (CAG 2018).

Developing countries are seeking to get a position in this industry too. Tehran's International Airport is in the early phases of a gradual improvement, a long-term plan to boost trade and turn Iran into a regional hub, hoping to compete with successful airports in special zones of the area such as airports in the United Arab Emirates and Turkey. New terminals and a vast airport free-trade area that includes sections for industry, logistics, hotels and conference centres are somehow in the centre of such a hope to convince foreign companies and international carriers to start choosing Tehran over other regional hubs. However, it is questionable, which criteria could lead to full-scale efficiency of hub airports especially in developing countries such as Iran that have not yet used this opportunity. Previous studies show this efficiency is largely based on competitive cost structure, a strong brand image, sustainable performance and efficient operation (Piltz et al. 2018; O'Connell 2011; Fitch 2016). The number of quantitative studies about hub excellence focusing from comprehensive perspective is not high. That is why this paper is about to investigate indicators related to hub performance excellence from various angles, considering leading hub airports performance while determining the priorities in order to help airports especially in developing countries to find the way of progress. A list of KPIs is prepared from the literature, which is prioritized using BWM, then using five most important criteria, MACBETH ranking approach is applied to analyse 19 Iranian international airports and find the most appropriate one for being hub airport.

In the Section 1, the literature of airport KPIs, BWM MCDM, interval type-2 fuzzy numbers and MACBETH methods are reviewed. The research methodology is explained in Section 2, and discussion and managerial implications are presented in Section 3. Finally, the last section concludes the paper, including suggestions for further research.

\section{Literature review}

\subsection{Airport KPIs}

Since about 70s, performance management has gained much more attention changing the view angle from financial point to multidimensional perspective, leading to new system of performance evaluation. Today each organization in each industry is ever more willing to improve its PMS (Halpern, Pagliari 2008; Bezerra, Gomes 2016a). It 
is noticeable that airports management have mostly transformed from governmental to private sector. Benchmarking and performance improvement has become a burgeoning area as a result (Baltazar et al. 2018).

For covering the purpose of this study, the literature has emphasized the design and implementation of PMS of airports. It is clear that contrary to initial studies, recent studies have set performance analysis system from much more holistic approach considering financial and non-financial factors simultaneously.

Various scholars have focused on airport performance appraisal form different aspects. Enoma and Allen (2007) developed and tested a set of key performance factors for airport management, with the focus on safety and security. Data was collected from ways such as interviews, workshops and the internet by use of case study methodology.

Schmidberger et al. (2009) put their main attention on ground handling services at European hub airports and developed a PMS for benchmarking by use of action research method for one year. The result is a PMS containing a process-based perspective with the focus on the supply chain of airport logistics.

Lozano et al. (2013) put their main attention on developing DEA model and its application to airports' performance comparison. They considered two process ("aircraft movement" and "aircraft loading") with two final outputs ("annual passenger movement" and "annual cargo handled"), one intermediate product ("aircraft traffic movements") and two undesirable outputs ("number of delayed flights" and "accumulated flight delays") to evaluate Spanish airports performances for year 2008.

However, Lai et al. (2015) compared efficiency between different samples of airports. This study has applied AHP, DEA and DEA-AR models, with number of employees, number of gates, number of runways, size of terminal area, length of runways and operational expenditures as outputs of DEA-AR model, while number of passengers, amount of freight and mail, aircraft movements and total revenue as inputs. Performances of 24 major international airports are compared in this empirical analysis. Of course, other scholars have also addressed this issue with different indicators and use of DEA modelling (Wanke 2012; Olfat et al. 2016; Olfat, Pishdar 2017; Wanke et al. 2016; Lo Storto 2018; Ennen, Batool 2018).

Bezerra and Gomes (2016a) fit a measurement model for perceived airport service quality by a multidimensional approach in order to become able to face the complexity of the airport service environment. Conformity factor analysis showed that check-in, security, convenience, ambience, basic facilities and mobility constitute the elements that should be measured to evaluate airport's service quality. The model is validated for international and domestic departing passengers. Of course, there are other studies that have focused on the quality of the airport's services delicately. Lee and $\mathrm{Yu}$ (2018) showed that user-generated online contents can be used as a data-source for assessing airport service quality. Pantouvakis and Renzi (2016) also pointed to this point that different nationalities perceive airport service qualities differently and that is why airports management should try to upgrade services according to passenger tastes with different cultures.

Eshtaiwi et al. (2017) evaluated the performance of three international Libya airports of Mitiga, Misurata and Al-Abraq by considering grey theory and five aspects of service quality, airport operations, airport economy, safety and security and environmental impact. In this way, it becomes possible to do benchmarking correctively and set the path to performance improvement.

Mirković and Tošić (2017) paid attention to differences between hub and non-hub airports only based on airside capacity under different traffic characteristics. The main finding is that functional relationship between the runway system and aprons is much stronger in the case of hub airports, and should be carefully considered when analysing airside capacity.

Meanwhile, Cahill et al. (2017) considered the case of Ireland's Dublin Airport authority for making investigations about the effects of commercialization on airport labour productivity and total factor productivity. Results do not show continuous upward trend in total factor productivity by continued commercialization over the 1994-2014 period. However, it is notable that long-term benefits of investment in physical capacity will not be immediately revealed in any productivity analysis. There are other studies that have considered the airport commercialization too (e.g. Freathy, O'Connell 1999; Yang et al. 2008; Castro, Lohmann 2014; Chung et al. 2017; Puls, Lentz 2018).

Keshavarz Ghorabaee et al. (2017) evaluated five airlines based on 28 service quality criteria. Several different MCDM methods are applied for evaluating the alternatives.

Bezerra and Gomes (2018) investigated key aspects of airport performance measurement practices by systematic literature review. The results revealed that safety, economic-financial, and service quality are in the main of concern. In contrast, competition, long-term economic results, and the environmental and social outcomes of the airport activities are not yet totally considered. Therefore, PMS of this industry should be broadened to present airports as business systems.

However, Baltazar et al. (2018) used MACBETH approach to set a hierarchical additive value model by use of expert's judgments. Safety and security, core, productivity/cost effectiveness, service quality, financial/commercial and environmental factors are the main elements constituted the performance evaluation model.

Eshtaiwi et al. (2018) determined a list of essential airport KPIs to provide a practical framework to measure and put under control the performance of Libyan airports over time. They also used AHP technique to set the weights of the KPIs and to compare airports in Libya according to the judgments of experts.

Considering previous related studies, initial KPIs for airports are set and finalized via experts' opinions that their characteristics are described in research methodology section (Table 1). 
Table 1. Initial KPIs for airports

\begin{tabular}{|c|c|c|}
\hline KPA & KPI & References \\
\hline $\begin{array}{l}\text { Strategic } \\
\text { management }\end{array}$ & $\begin{array}{l}\text { - mission and vision statement of sustainable development; } \\
\text { - value chain coordination; } \\
\text { - development of trade policies related to sustainable development; } \\
\text { - consideration of sustainability standards } \\
\text { - human resource management; } \\
\text { - research and development; } \\
\text { - design and construction of the airport environment based on sustainability principles; } \\
\text { - governmental legislations }\end{array}$ & $\begin{array}{l}\text { Berry et al. }(2018) \\
\text { CDA }(2013) ; \\
\text { ICAO (2012); } \\
\text { OECD (2001); } \\
\text { SAGA (2018) }\end{array}$ \\
\hline $\begin{array}{l}\text { Airport } \\
\text { branding }\end{array}$ & $\begin{array}{l}\text { - public image; } \\
\text { - airport reputation; } \\
\text { - brand value }\end{array}$ & $\begin{array}{l}\text { Bond (2013); } \\
\text { Castro, Lohmann (2014); } \\
\text { Lee, Park (2016) }\end{array}$ \\
\hline $\begin{array}{l}\text { Airport } \\
\text { connectivity }\end{array}$ & $\begin{array}{l}\text { - direct connectivity; } \\
\text { - indirect connectivity; } \\
\text { - hub connectivity }\end{array}$ & $\begin{array}{l}\text { ACI (2017); } \\
\text { Burghouwt et al. (2009); } \\
\text { O’Connell, Bueno (2018); } \\
\text { Tłoczyński (2017) }\end{array}$ \\
\hline Productivity & $\begin{array}{l}\text { - expenditure per passenger measured per year; } \\
\text { - income per passenger measured per year; } \\
\text { - non-aeronautical income per passenger measured per year; } \\
\text { - revenue per } \mathrm{m}^{2} \text { of floor space measured per year; } \\
\text { - total cost per WLU measured per year }\end{array}$ & $\begin{array}{l}\text { Eshtaiwi et al. (2018); } \\
\text { Schmidberger et al. (2009) }\end{array}$ \\
\hline Financial & $\begin{array}{l}\text { - aeronautical revenue per passenger; } \\
\text { - aeronautical revenue per movement; } \\
\text { - non-aeronautical operating revenue as percent of total operating revenue; } \\
\text { - non-aeronautical operating revenue per passenger; } \\
\text { - debt service as percentage of operating revenue; } \\
\text { - long-term debt per passenger; } \\
\text { - debt to EBITDA ratio; } \\
\text { - EBITDA per passenger }\end{array}$ & $\begin{array}{l}\text { BAC (2014); } \\
\text { Bezerra, Gomes (2018); } \\
\text { CDA (2013); } \\
\text { Eshtaiwi et al. (2018); } \\
\text { ICAO (2013); } \\
\text { Rodgers (2015); } \\
\text { Schmidberger } \text { et al. (2009) }\end{array}$ \\
\hline $\begin{array}{l}\text { Safety and } \\
\text { security }\end{array}$ & $\begin{array}{l}\text { - runway accidents; } \\
\text { - runway incursions; } \\
\text { - bird strikes; } \\
\text { - public injuries; } \\
\text { - occupational injuries; } \\
\text { - lost work time from employee accidents and injuries; } \\
\text { - hygiene monitoring }\end{array}$ & $\begin{array}{l}\text { ACI (2012); } \\
\text { Bezerra, Gomes (2018); } \\
\text { Enoma, Allen (2007) }\end{array}$ \\
\hline $\begin{array}{l}\text { Social } \\
\text { responsibility }\end{array}$ & $\begin{array}{l}\text { - community involvement; } \\
\text { - human rights; } \\
\text { - social programs; } \\
\text { - number of jobs created per percent by women, minorities, disabled people of the total } \\
\text { - workforce; } \\
\text { - sporting/social/cultural sponsorship; } \\
\text { - number of activities focused on community; } \\
\text { - media contacts }\end{array}$ & $\begin{array}{l}\text { Bezerra, Gomes (2016b, } \\
\text { 2018); } \\
\text { CDA (2013); } \\
\text { ICAO (2012); } \\
\text { SAGA (2018) }\end{array}$ \\
\hline $\begin{array}{l}\text { Environmen- } \\
\text { tal protection }\end{array}$ & $\begin{array}{l}\text { - carbon footprint; } \\
\text { - waste recycling; } \\
\text { - waste reduction percentage; } \\
\text { - renewable energy purchased by the airport [\%]; } \\
\text { - utilities/energy usage per square meter of terminal; } \\
\text { - water consumption per passenger; } \\
\text { - noise reduction }\end{array}$ & $\begin{array}{l}\text { BAC (2014); } \\
\text { Berry et al. (2018); } \\
\text { Bezerra, Gomes (2018); } \\
\text { ICAO (2012); } \\
\text { Monsalud et al. (2015) }\end{array}$ \\
\hline $\begin{array}{l}\text { Service } \\
\text { quality }\end{array}$ & $\begin{array}{l}\text { - SERVQUAL elements (tangibility, reliability, responsiveness, assurance, empathy); } \\
\text { - enjoyment and refinement of the environment; } \\
\text { - consideration of passengers' nationality in servicing; } \\
\text { - turn-around process time; } \\
\text { - number of runways; } \\
\text { - number of delayed flights measured per day; } \\
\text { - length of runway taxi departure delay measured per day; } \\
\text { - number of boarding; } \\
\text { - number of baggage collection belts; } \\
\text { - check-in waiting times; } \\
\text { - baggage delivery time waiting time at security control; } \\
\text { - customer satisfaction monitoring }\end{array}$ & $\begin{array}{l}\text { ACI (2012); } \\
\text { Bezerra, Gomes (2016a); } \\
\text { Eshtaiwi et al. (2018); } \\
\text { Lee, Yu (2018); } \\
\text { Pantouvakis, Renzi } \\
\text { (2016); } \\
\text { SAGA (2018) }\end{array}$ \\
\hline $\begin{array}{l}\text { Competitive- } \\
\text { ness }\end{array}$ & $\begin{array}{l}\text { - market share for airports; } \\
\text { - airline competition at the airport; } \\
\text { - number of destinations (non-stop); } \\
\text { - airline operating expenses per passenger at the airport }\end{array}$ & Bezerra, Gomes (2016b) \\
\hline
\end{tabular}




\subsection{BWM - MCDM method}

BWM is one of the new MCDM techniques presented by Rezaei (2015). In this method, the best and worst indicator is determined by the decision maker, and a pair comparison between each these two (best and worst) indicators and other indicators are then formulated and resolved; a minimization model is designed to calculate the weight of the various indicators. In addition, in this method, a formula for calculating the in CR to test the validity of the comparisons in mind is taken. Among the prominent features of this method, several factors of decision-making are that it needs less comparative data and this method leads to comparisons that are more robust; that is, it provides more reliable answers (Brunelli, Rezaei 2019).

After determination of criteria, the most important and least important criterion is to be found among all the indicators that are called best and worst, and then the comparison of all other criteria is done pairwise with the best criteria and other criteria with the worst criteria in the form of two matrices. In the next step, a linear model should be constituted as is depicted in Equation (1). The weights are determined by solving the linear model (Brunelli, Rezaei 2019).

$\min \varepsilon$

subject to:

$$
\begin{aligned}
& \left|w_{b}-a_{B j} \cdot w_{j}\right| \leq \varepsilon ; \\
& \left|w_{j}-a_{j w} \cdot w_{w}\right| \leq \varepsilon ; \\
& \sum_{j} w_{j}=1 ;
\end{aligned}
$$

$w_{j} \geq j$, for all $j$.

By consideration of the $\varepsilon$ value and the related value in Table 2, CR can be determined. The closer to 0 , the more compatibility of the comparisons has been created, and the closer to one, the comparisons have less compatibility and less stability. CI, which is used to determine CR can be reached via Table 2 . The CR is specified by use of Equation (2):

$$
C R=\frac{\varepsilon}{C I} .
$$

Table 2. Values of CI

\begin{tabular}{|l|c|c|c|c|c|c|c|c|c|}
\hline Number & 1 & 2 & 3 & 4 & 5 & 6 & 7 & 8 & 9 \\
\hline CI & 0 & 0.44 & 1 & 1.63 & 2.3 & 3 & 3.73 & 4.47 & 5.23 \\
\hline
\end{tabular}

\subsection{Interval type- 2 fuzzy numbers}

Fuzzy sets are considered while analysis of the experts' opinions. However, membership function in type-1 fuzzy sets does not show any ambiguity although the fuzzy concept contains lots of uncertainty; this caused the introduction of type-2 fuzzy sets by Zadeh (1975) by extending the concept of type-1 fuzzy set (Wu, Mendel 2007, 2008). In type-2 fuzzy sets, membership function is itself a type-1 fuzzy number. Since, using type-2 fuzzy sets are somewhat sophisticated; interval type- 2 fuzzy sets are used in many aspects. In interval type- 2 fuzzy numbers, uncertainty of membership function is shown by interval value - see Equation (3) - (Hu et al. 2013). An interval type-2 fuzzy illustration of a crisp number like $C$, is defined as $(c, c, c$, c; 1, 1) (Abdullah, Zulkifli 2015).

Considering $A, B$ as two trapezoidal interval type-2 fuzzy numbers, laws of calculations are as follow:

$$
\begin{aligned}
& A=\left(A^{U}, A^{L}\right)= \\
& \left(\left(a_{1}^{U}, a_{2}^{U}, a_{3}^{U}, a_{4}^{U} ; H_{1}\left(A^{U}\right), H_{2}\left(A^{U}\right)\right)\right. \\
& \left.\left(a_{1}^{L}, a_{2}^{L}, a_{3}^{L}, a_{4}^{L} ; H_{1}\left(A^{L}\right), H_{2}\left(A^{L}\right)\right)\right) ; \\
& B=\left(B^{U}, B^{L}\right)= \\
& \left(\left(b_{1}^{U}, b_{2}^{U}, b_{3}^{U}, b_{4}^{U} ; H_{1}\left(B^{U}\right), H_{2}\left(B^{U}\right)\right)\right. \\
& \left.\left(b_{1}^{L}, b_{2}^{L}, b_{3}^{L}, b_{4}^{L} ; H_{1}\left(B^{L}\right), H_{2}\left(B^{L}\right)\right)\right) ; \\
& A+B=\left(A^{U}, A^{L}\right)+\left(B^{U}, B^{L}\right)= \\
& \left(\left(a_{1}^{U}+b_{1}^{U}, a_{2}^{U}+b_{2}^{U}, a_{3}^{U}+b_{3}^{U}, a_{4}^{U}+b_{4}^{U} ;\right.\right. \\
& \left.\min \left(H_{1}\left(A^{U}\right), H_{1}\left(B^{U}\right)\right), \min \left(H_{2}\left(A^{U}\right), H_{2}\left(B^{U}\right)\right)\right) \\
& \left(a_{1}^{L}+b_{1}^{L}, a_{2}^{L}+b_{2}^{L}, a_{3}^{L}+b_{3}^{L}, a_{4}^{L}+b_{4}^{L} ;\right. \\
& \left.\left.\min \left(H_{1}\left(A^{L}\right), H_{1}\left(B^{L}\right)\right), \min \left(H_{2}\left(A^{L}\right), H_{2}\left(B^{L}\right)\right)\right)\right) ; \\
& A-B=\left(A^{U}, A^{L}\right)-\left(B^{U}, B^{L}\right)= \\
& \left(\left(a_{1}^{U}-b_{4}^{U}, a_{2}^{U}-b_{3}^{U}, a_{3}^{U}-b_{2}^{U}, a_{4}^{U}-b_{1}^{U} ;\right.\right. \\
& \left.\min \left(H_{1}\left(A^{U}\right), H_{1}\left(B^{U}\right)\right), \min \left(H_{2}\left(A^{U}\right), H_{2}\left(B^{U}\right)\right)\right) \\
& \left(a_{1}^{L}+b_{4}^{L}, a_{2}^{L}-b_{3}^{L}, a_{3}^{L}-b_{2}^{L}, a_{4}^{L}-b_{1}^{L} ;\right. \\
& \left.\left.\min \left(H_{1}\left(A^{L}\right), H_{1}\left(B^{L}\right)\right), \min \left(H_{2}\left(A^{L}\right), H_{2}\left(B^{L}\right)\right)\right)\right) ; \\
& \frac{1}{k}(A)=\left(\left(\frac{1}{k} \cdot a_{1}^{U}, \frac{1}{k} \cdot a_{2}^{U}, \frac{1}{k} \cdot a_{3}^{U}, \frac{1}{k} \cdot a_{4}^{U} ; H_{1}\left(A^{U}\right), H_{2}\left(A^{U}\right)\right)\right. \\
& \left.\left(\frac{1}{k} \cdot a_{1}^{L}, \frac{1}{k} \cdot a_{2}^{L}, \frac{1}{k} \cdot a_{3}^{L}, \frac{1}{k} \cdot a_{4}^{L} ; H_{1}\left(A^{L}\right), H_{2}\left(A^{L}\right)\right)\right) ; \\
& A \otimes B=\left(A^{U}, A^{L}\right) \cdot\left(B^{U}, B^{L}\right)= \\
& \left(\left(a_{1}^{U} \cdot b_{1}^{U}, a_{2}^{U} \cdot b_{2}^{U}, a_{3}^{U} \cdot b_{3}^{U}, a_{4}^{U} \cdot b_{4}^{U} ;\right.\right. \\
& \min \left(H_{1}\left(A^{U}\right), H_{1}\left(B^{U}\right)\right), \min \left(H_{2}\left(A^{U}\right), A_{2}^{L} ;\right. \\
& \left.\left.\left.\left.\min ), H_{2}\left(B^{L}\right)\right)\right)\right)\right)
\end{aligned}
$$

Scale that is shown in Table 3 can be applied to gather experts' opinions. Then, opinions of all experts are determined and the mean of them is specified by use of Equation (7). 
Table 3. The scale used in data gathering

\begin{tabular}{|c|c|}
\hline $\begin{array}{l}\text { Linguistic } \\
\text { variables }\end{array}$ & $\begin{array}{l}\text { The equivalent interval type-2 fuzzy number } \\
\text { in the format of: } \\
\qquad\left(\left(a_{1}^{U}, a_{2}^{U}, a_{3}^{U}, a_{4}^{U} ; H_{1}\left(A^{U}\right), H_{2}\left(A^{U}\right)\right),\right. \\
\left.\left(a_{1}^{L}, a_{2}^{L}, a_{3}^{L}, a_{4}^{L} ; H_{1}\left(A^{L}\right), H_{2}\left(A^{L}\right)\right)\right)\end{array}$ \\
\hline Strongly agree & $\begin{array}{c}((0.8,0.9,0.9,1 ; 1,1) \\
(0.85,0.9,0.9,0.95 ; 0.9,0.9))\end{array}$ \\
\hline Agree & $\begin{array}{c}((0.6,0.7,0.7,0.8 ; 1,1) \\
(0.65,0.7,0.7,0.75 ; 0.9,0.9))\end{array}$ \\
\hline Undecided & $\begin{array}{c}((0.4,0.5,0.5,0.6 ; 1,1) \\
(0.45,0.5,0.5,0.55 ; 0.9,0.9))\end{array}$ \\
\hline Disagree & $\begin{array}{c}((0.2,0.3,0.3,0.4 ; 1,1) \\
(0.25,0.3,0.3,0.35 ; 0.9,0.9))\end{array}$ \\
\hline $\begin{array}{l}\text { Strongly } \\
\text { disagree }\end{array}$ & $\begin{array}{c}((0,0.1,0.1,0.1 ; 1,1) \\
(0,0.1,0.1,0.05 ; 0.9,0.9))\end{array}$ \\
\hline
\end{tabular}

In this regard, value of each variable is determined and the upper and lower limits of values are specified considering Equations (9) and (10):

$$
\begin{aligned}
& M_{*}(A)=\frac{1}{6} \cdot\left(a_{1}^{U}+2 a_{2}^{U}\right) \cdot h_{1}^{U}+\frac{1}{6} \cdot\left(a_{1}^{L}+2 a_{2}^{L}\right) \cdot h_{1}^{L} ; \\
& M^{*}(A)=\frac{1}{6} \cdot\left(a_{4}^{U}+2 a_{3}^{U}\right) \cdot h_{2}^{U}+\frac{1}{6} \cdot\left(a_{4}^{L}+2 a_{3}^{L}\right) \cdot h_{2}^{L} .
\end{aligned}
$$

\subsection{MACBETH model}

MACBETH is an approach that uses pair judgments about the attractiveness differences of alternatives to quantify the amount of attractiveness of each (Bana e Costa, Vansnick 1999). What makes it friendlier is that via questioning about each two of alternatives, which are called "option" in this method and also in the M-MACBETH software, by giving qualitative judgment, the user can transfer whole comparative answers.

As the comparative values are introduced into the MMACBETH software, which is designed as a DSS, it starts verifying their consistency then makes a numerical scale according to the decision maker's judgments. Same process happens to calculate criteria's weights. Furthermore, it provides tools to facilitate several types of sensitivity analyses.

A decision tree is then created in the M-MACBETH, listing the criteria. The options, which are airports in this research, then will be introduced into the model.

Next, qualitative judgments regarding the difference of attractiveness between options are elicited from the decision maker, who then chooses among 6 predefined answers such as "very weak", "weak", "moderate", "strong", "very strong" and "extreme". If unsure about the difference of attractiveness he can choose more than one qualitative rating also.

When each judgement is given, the software automatically verifies the matrix's consistency, and suggests judgement modification(s) that could be made to fix any possible detected inconsistency, which helps decision maker correct his mindset.
Although M-MACBETH works as a DSS, here the mathematics of this method is summarized. If decision maker ranks option $X_{i}$ higher than $X_{j}$ for the criterion $k$, it will be:

$$
X_{i} \succ X_{j}
$$

As explained above, the decision maker chooses one of the six answers to define his preference that is quantified as $h=\{0,1,2,3,4,5,6\}$ so it will be:

$$
X_{i} \succ{ }^{h} X_{j}
$$

This means:

$$
X_{i}-X_{j}=h \cdot a \text {. }
$$

In MACBETH each alternative will have a score in $[0,100]$ interval so $a$ is a coefficient for score differences. The score assigned to the most preferred alternative is 100 and to the less preferred one is 0 , it's shown as by $v_{j}\left(X_{i}\right)$ According to the pairwise matrix of criteria, filled by the decision maker, these scores can be calculated. Then from Equation (13), the overall value of alternatives can be found:

$$
\begin{aligned}
& V\left(X_{i}\right)=\sum_{j=1}^{n} w_{j}\left(v_{j}\left(X_{i}\right)\right) ; \\
& \sum_{j=1}^{n} w_{j}, w_{j} \succ 0 .
\end{aligned}
$$

Alternative with highest $V\left(X_{i}\right)$ is the most preferred one and others will be ranked accordingly.

There are several examples of MACBETH application in different industries in the literature; Santa Catarina textile industry strategic planning (Bana e Costa et al. 1999), analysis of investment in the new inter-municipal road-links (Bana e Costa 2001), railway construction problem (Bana e Costa et al. 2001), preventive maintenance management in a municipal housing stock (Bana e Costa, Oliveira 2002), strategic metropolitan decisions (Bana e Costa et al. 2002b), credit assignment algorithms in banking systems (Bana e Costa et al. 2002c), bid evaluation systems (Bana e Costa et al. 2002a), career selection (Bana e Costa, Chagas 2004), stable government coalition structure (Roubens et al. 2006), industrial performance assessment system (Clivillé et al. 2007), bridges and tunnels prioritization in earthquake risk mitigation (Bana e Costa et al. 2008), hydrogen storage technologies performance evaluation (Montignac et al. 2009), customer satisfaction assessment (Fakhfakh et al. 2011), supplier selection (Karande, Chakraborty 2013), healthcare performance indicators (Rodrigues 2014), facility location selection (Karande, Chakraborty 2014), performance satisfaction level (Pourhejazy et al. 2019).

\section{Research methodology}

Many scholars and experts have come to notice set of indicator effective in making airports the hub ones. This can be more useful about airports in developing countries 
with less experience in comparison to airports in developed countries.

For gaining this aim, the components are determined by literature review and concluded by professionals of Iran airports holding company and writers of the related papers in other countries. These experts know the concept of making airports hub and the situation of airports in developing countries as a whole. They also have experiences of airports' visions determination. As a result, their opinions can be trustful.

The weights of these criteria are specified using interval type-2 fuzzy BWM. As BWM is one of the latest MADM methods, it was chosen to efficiently tackle the inconsistency derived from pairwise comparisons. This method is more consistent compared to many famous methods such as AHP, ANP, FARE and SMART methods (Hashemkhani Zolfani, Chatterjee 2019). Indicators are ranked through their obtained weights to evaluate the most suitable Iranian passenger airports with Macbeth technique in order to see which one of these airports is more ready to become hub at the moment. The MACBETH method is selected for this step because of its simplicity, as well as its user-friendly manner, which helps respondents feel relax as they can transfer whole comparative answers by giving qualitative judgment in the M-MACBETH software. Initial screening is done via investigation of official documents keeping in Iran airports holding company office.

The total number of 54 airports is there in Iran, 19 of which are counted as international ones based on statistics of Iran airports holding company. Many of them are not profitable at the moment and the non-aviation income is far less than the average global rate. Another matter is that these airports may not be experienced in communicating with local shareholders or may encounter natural disasters. Some of them also have difficulties in preserving local species. Gaining such characteristics makes the airport more sustainable and this is while previous studies show that hub airports usually have more effective sustainability performance (Carlucci et al. 2018; Scholz, Von Cossel 2011). Therefore, determination of the readiest Iranian airports in regards to becoming a hub, can bring various values for government and people at the same time. The main steps of this study are depicted in Figure 1.

\section{Discussion and managerial implications}

Finalized set of indicators depicted in Table 1 is weighted via experts' opinions, who are 16 anonymous experts of Iran airports holding company chosen by top manager of the company to cooperate in the research. However, they have been asked to choose the most important one and the least important item at the beginning. These are named as best and worst indicators in BWM technique. First, each expert identifies the preference of the first criteria as compared to other indicators. After that, the priority of other indicator is determined in comparison with the worst indicator. Each expert has announced his opinion considering the scale in Table 2. Then, the averages of opinions about each indicator are specified via consideration of Equations (5) and (6). In this step, values of $a_{B j}$ and $a_{j w}$ are obtained. Two linear models are solved to gain the upper limit and lower limit of interval type-2 fuzzy weights - see Equation (1). These values are observable in Table 4.

Since epsilon value while determination of upper limit value of weight and lower limit value of weight is respectively equal to 0.066 and 0.064 , the CRs will be equal to 0.0126 and 0.0121 . These rates are so close to 0 and one can claim that comparisons have a good compatibility.

Hereafter, by substituting the upper $\bar{E}$ and lower $\underline{E}$ limits values in Equation (16); the possibility degrees of preferences about indicator can be calculated. Same way, the matrix of possibility degrees of preferences about indicator is obtained - Equation (17). Each row of this reflects possibility degrees of preferences of an indicator against other ones. This matrix surely contains a row with degrees of equal or more than 0.5 value. The related indicator gets the first rank in this way. Other indicators are ranked after elimination of row and column of the mentioned indicator as such (Hashemi et al. 2014).

$$
\begin{aligned}
& \quad P\left(E_{2} \succ E_{1}\right)=\frac{b_{1}}{b_{2}}, \\
& \text { where: } \\
& \quad b_{1}=\max \left(0,\left(\bar{E}_{2}-\underline{E}_{2}\right)+\left(\bar{E}_{1}-\underline{E}_{1}\right)\right)- \\
& \quad \max \left(0,\left(\bar{E}_{1}-\underline{E}_{2}\right)\right) ; \\
& b_{2}=\left(\bar{E}_{2}-\underline{E}_{2}\right)+\left(\bar{E}_{1}-\underline{E}_{1}\right) .
\end{aligned}
$$

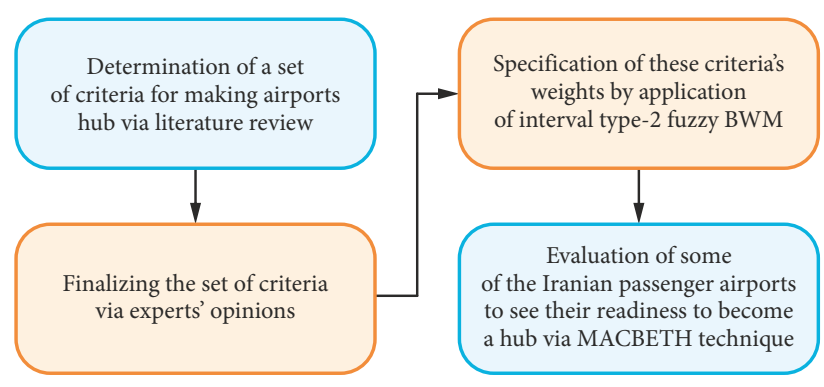

Figure 1. Main steps of this study

Table 4. The weights of indicators via application of BWM plus their ranks

\begin{tabular}{|l|c|c|c|}
\hline \multicolumn{1}{|c|}{ Indicator } & $\begin{array}{c}\text { Lower limit } \\
\text { value }\end{array}$ & $\begin{array}{c}\text { Upper limit } \\
\text { value }\end{array}$ & Ranks \\
\hline Strategic management & 0.1133 & 0.1135 & 1 \\
\hline Airport branding & 0.1114 & 0.1116 & 2 \\
\hline Airport connectivity & 0.1095 & 0.1097 & 3 \\
\hline Productivity & 0.1076 & 0.1078 & 4 \\
\hline Financial & 0.0697 & 0.0706 & 9 \\
\hline Safety and security & 0.10567 & 0.10593 & 6 \\
\hline Social responsibility & 0.1037 & 0.1040 & 7 \\
\hline $\begin{array}{l}\text { Environmental } \\
\text { protection }\end{array}$ & 0.1018 & 0.1021 & 8 \\
\hline Service quality & 0.0697 & 0.0706 & 9 \\
\hline Competiveness & 0.10420 & 0.10510 & 5 \\
\hline
\end{tabular}




$$
\begin{aligned}
& \text { Indicator } 1 \quad \ldots \quad \text { Indicator } 10 \\
& P=\quad \vdots \quad \begin{array}{llll}
\text { Indicator } 1 \\
\quad \text { Indicator 10 }
\end{array}\left(\begin{array}{cccc}
P\left(E_{1} \succ E_{1}\right) & P\left(E_{1} \succ E_{2}\right) & \ldots & P\left(E_{1} \succ E_{10}\right) \\
P\left(E_{2} \succ E_{1}\right) & P\left(E_{2} \succ E_{2}\right) & \ldots & P\left(E_{2} \succ E_{10}\right) \\
\vdots & \vdots & \ldots & \vdots \\
P\left(E_{10} \succ E_{1}\right) & P\left(E_{10} \succ E_{2}\right) & \ldots & P\left(E_{10} \succ E_{10}\right)
\end{array}\right)
\end{aligned}
$$

Ranks of indicators are specified via use of Equations (16) and (17) and are depicted in Table 4. Such result is transferred to experts again for gaining a realistic interpretation. As is obvious, service quality is the most tangible indicator of the airport's performance and always has been under control by taking comments from passengers or use of famous models such as SERVQUAL. It is actually among the first indicators to be investigated and always considered while policy making. Now, airport managers in developing countries are familiar enough with its related principles and benchmarking system. However, "system and security" is still a threat in such countries although its importance is obvious. In the history of aviation in Iran for instance, the death toll of 1694 people has been recorded for aircraft owned or leased by Iranian air companies or Iran airports holding company. This is because of the weakness in operation of aircraft safety standards or any other reason; it shows that this indicator should receive more attention. Another important indicator, which was not under consideration until recently is about airport branding. Governments are taking the pass through privatization of airports in recent decades and that is why airport managers are forced to place greater emphasis on airport marketing and branding (Castro, Lohmann 2014). Brand management helps airports to differentiate themselves from competitors and be chosen by passengers as final destination or a hub. Such branding helps airports to increase their connectivity as hubs. Besides, studies show that airport brand management enhances performance transparency, and social-environmental responsibility, resulting to sustainability (Lee, Park 2016; Figueiredo, Castro 2019). However, airport managers in developing countries are still inexperienced in this domain. It is advised to take use of leader airports such as Heathrow Airport near London or Singapore Changi Airport to symbolizing brands and create lovable brand. In this way, it becomes possible to shape a unique image in passengers' minds and also show the importance of local species and culture preservation at the same time. It also creates a pleasant atmosphere, which makes waiting to continue air travel as hubs easier. All of these activities, which seeks to distinct airport from competitors and enhance its productivity of performance should be considered in airport vision when policy-making. Then, airport will become a commercial business and not just a way for transportation. Now, it can be seen that financial concept and revenue value has not a considerable importance by itself and the way it will be used gains more importance; a matter that should be investigated while policy-making.
Table 5. The list of Iranian international airports

\begin{tabular}{|l|c|}
\hline \multicolumn{1}{|c|}{ Airport's name } & ICAO code \\
\hline Abadan & OIAA \\
\hline Ahvaz & OIAW \\
\hline Ardabil & OITL \\
\hline Bandar Abbas & OIKB \\
\hline Shahid Beheshti of Isfahan & OIFM \\
\hline Payam & OIIP \\
\hline Hashemi Rafsanjani of Kerman & OIKK \\
\hline Ashrafi Isfahani of Kermanshah & OICC \\
\hline Kish & OIBK \\
\hline Larestan & OISL \\
\hline Hasheminejad of Mashad & OIMM \\
\hline Pars Abad of Moghan & OITP \\
\hline Dashte Naz of Sari & OINZ \\
\hline Dastgheib of Shiraz & OISS \\
\hline Madani of Tabriz & OITT \\
\hline Imam Khomeini & OIIE \\
\hline Mehrabad & OIII \\
\hline Oroumieh & OITR \\
\hline Zahedan & OIZH \\
\hline
\end{tabular}

Now using the first 5 criteria, the most appropriate Iranian international airport to be hub airport is found. The list of all 19 Iranian international airports is presented in Table 5 and their ICAO code is used to mention them now onwards.

The criteria are introduced in M-MACBETH and the value tree is as presented on Figure 2.

Then all the alternatives/options are compared pairwise to fill the judgement matrix for each criterion.

The results for each criterion are as shown in Figure 3; the ranking of airports according to each criterion is different from the overall result. In addition, the scores and differences between scores are completely different, for example it can be seen that "Airport branding" in Payam Airport with the ICAO code "OIIP" is better than other airports but in no other criterion this airport got the first level. The results are better reported in Figure 4.

Finally, the software calculates the overall ranking of alternatives considering all the criteria, which is shown in Figure 5.

As the results show, Kish Airport with the ICAO code "OIBK" is prior to other airports and can be chosen as the hub airport.

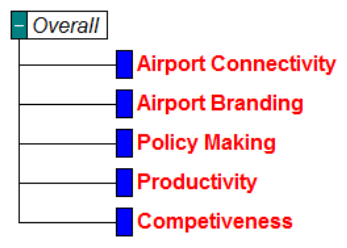

Figure 2. Value tree of the model 


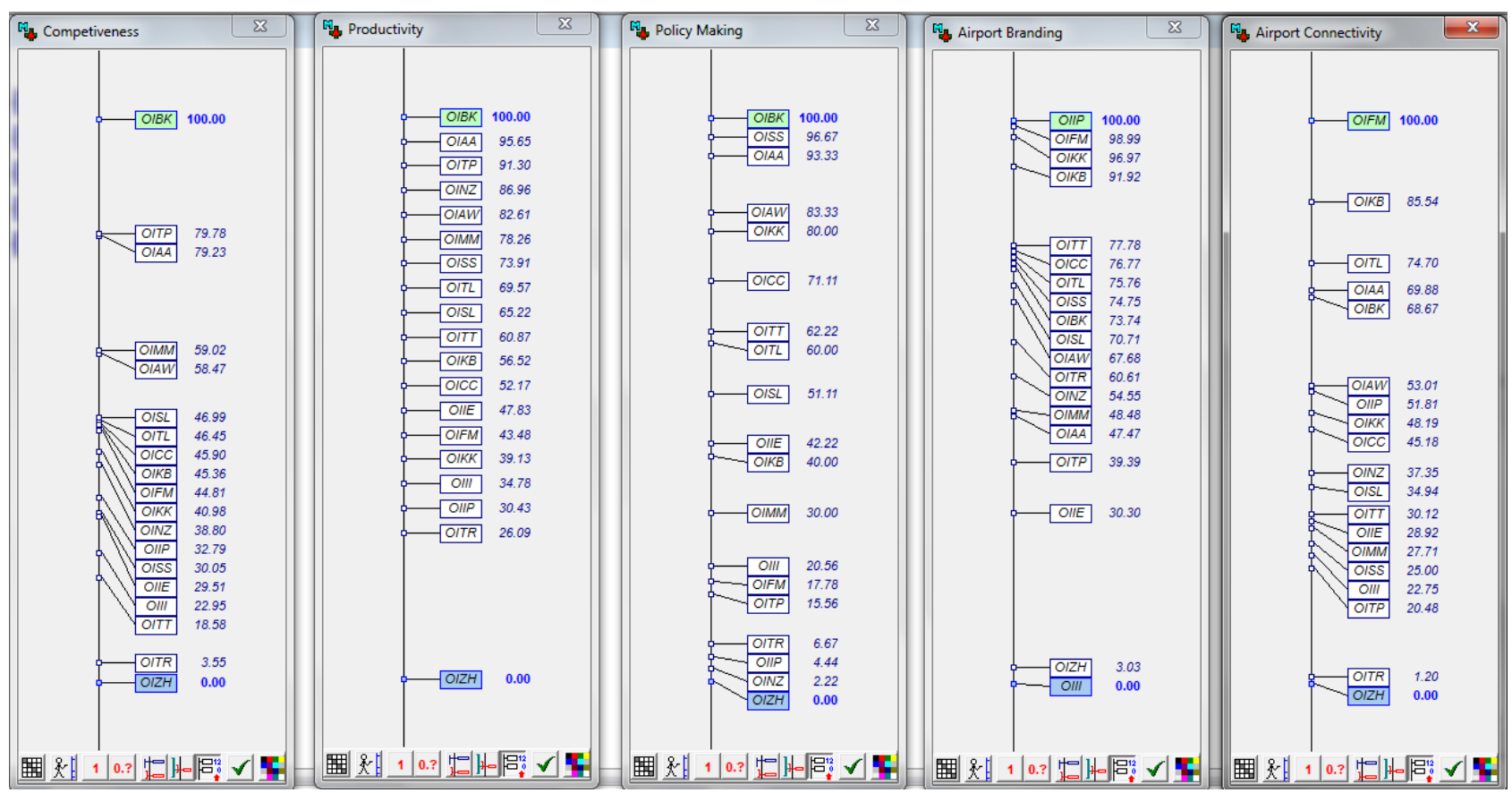

Figure 3. Alternatives' position according to each criterion

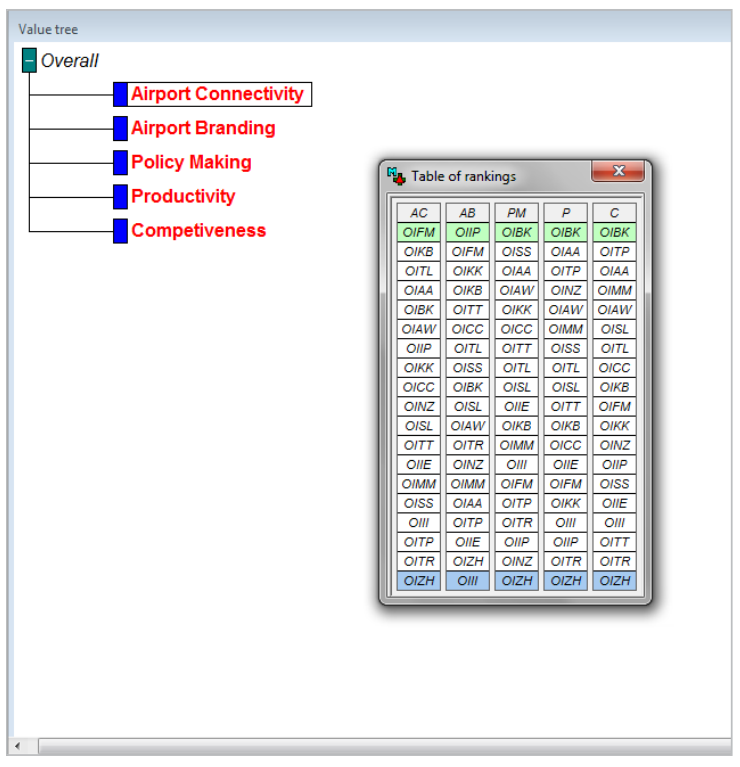

Figure 4. Table of alternatives' ranking according to each criterion

\section{Conclusions}

BWM is a new decision making method, which accurately can be used to rank different alternatives. In this paper, this method is used for criteria ranking in a situation that applying all found criteria in the chosen DSS isn't possible because the number of alternatives is too large and it increases the number of judgements very dramatically and consequently makes it difficult for experts to fill the matrix. As the criteria mentioned here are listed from previous studies in air transportation researches, comparing them with quantitative scores isn't simple for experts, so interval type- 2 fuzzy numbers are generated to simplify

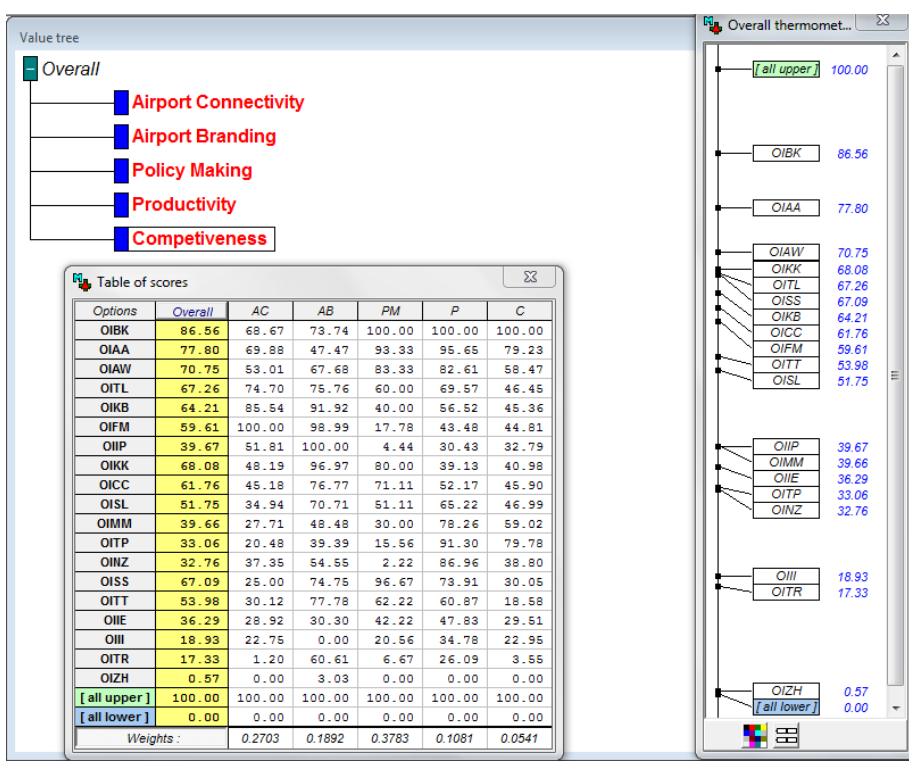

Figure 5. Overall calculations of alternatives' ranking

assessment process. Then by the use of M-MACBETH software, alternatives are compared considering each high-rank criterion specified in previous step, alternatives in this study are Iranian international airports. Up to our knowledge, its first time that this combined method is used to rank alternatives or make decisions especially using interval type-2 fuzzy numbers.

Air traffic is attracting more attention among other transportation systems because of its potential of financial gaining in different ways other than just transportation mode. This makes it critical for managers to decide about investments in each development project. This can be more critical in shadow of budget restrictions, that's why 
in developing countries like Iran although the intention for having a good position in international air transportation system is very high, but the process of development is slow mostly because of low investment and uncertainties in best place for investment.

As expressed before among 54 airports in Iran, 19 of them are known as international ones. Many of them are not beneficial recently and the non-aviation earning is far less than the average global rate. Another problem is that these airports may not be experienced in communicating with local shareholders or may encounter natural disasters. Some of them also have difficulties in preserving local species. Gaining such characteristics makes the airport more sustainable and this is while previous studies show that hub airports usually have more effective sustainability performance. The results show that Kish airport with the ICAO code "OIBK" is prior to other airports and can be chosen as the hub airport, although it's not located in capital of the country and in fact is far away from that, but as is located in a free zone island, it can be a logically acceptable choice for managers and experts.

Besides the main goal of this research to find the most appropriate airport to be the hub airport in Iran, the results can be used for airport managers to find their weak points in each airport. Rankings according to each criterion in Figure 3 show this, that was attractive for respondents also.

The proposed approach to decision making is suggested for other industries as well, the most important advantage of this method is the combination of fuzzy judgements and qualitative comparisons, which is main challenge for experts of different aspects.

\section{Author contributions}

Mahsa Pishdar and Fatemeh Ghasemzadeh conceived the study, designed and developed the methodology, made data collection and analysis, wrote the first draft of the article.

Jurgita Antuchevičienè provided extensive advice throughout the study, assisted with the research design and revised the manuscript. All of the authors have read and approved the final manuscript.

\section{Disclosure statement}

Authors declare that they have no any competing financial, professional, or personal interests from other parties.

\section{References}

Abdullah, L.; Zulkifli, N. 2015. Integration of fuzzy AHP and interval type-2 fuzzy DEMATEL: An application to human resource management, Expert Systems with Applications 42(9): 4397-4409. https://doi.org/10.1016/j.eswa.2015.01.021

ACI. 2018. Airport Economics 2018 Report: a Comprehensive View of The Industry's Financial Performance. ACI (Airports Council International). $84 \mathrm{p}$.
ACI. 2017. Airport Industry Connectivity Report 2017. ACI (Airports Council International). $44 \mathrm{p}$.

ACI. 2012. Guide to Airport Performance Measures. ACI (Airports Council International). 61 p. Available from Internet: http://www.aci.aero/Media/aci/downloads/ACI_APM_ Guidebook_2_2012.pdf

BAC. 2014. Land Use and Planning. Brisbane Airport Corporation (BAC), Brisbane, Australia. 28 p. Available from Internet: https://www.bne.com.au/sites/default/files/docs/BNR_EIS_ MDP_B2_Land_Use.pdf

Baltazar, M. E.; Rosa, T.; Silva, J. 2018. Global decision support for airport performance and efficiency assessment, Journal of Air Transport Management 71: 220-242.

https://doi.org/10.1016/j.jairtraman.2018.04.009

Bana e Costa, C. A. 2001. The use of multi-criteria decision analysis to support the search for less conflicting policy options in a multi-actor context: case study, Journal of Multi-Criteria Decision Analysis 10(2): 111-125.

https://doi.org/10.1002/mcda.292

Bana e Costa C. A.; Chagas, M. P. 2004. A career choice problem: an example of how to use MACBETH to build a quantitative value model based on qualitative value judgments, European Journal of Operational Research 153(2): 323-331. https://doi.org/10.1016/S0377-2217(03)00155-3

Bana e Costa, C. A.; Corrêa, É. C.; De Corte, J.-M.; Vansnick, J.-C. 2002a. Facilitating bid evaluation in public call for tenders: a socio-technical approach, Omega 30(2): 227-242. https://doi.org/10.1016/S0305-0483(02)00029-4

Bana e Costa, C. A.; Da Costa-Lobo, M. L.; Ramos, I. A.; Vansnick, J.-C. 2002b. Multicriteria approach for strategic town planning: the case of Barcelos, International Series in Operations Research \& Management Science 44: 429-456. https:// doi.org/10.1007/978-1-4615-0843-4_19

Bana e Costa, C. A.; Barroso, L. A.; Soares, J. O. 2002c. Qualitative modelling of credit scoring: a case study in banking, European Research Studies 5(1-2): 37-51.

Bana e Costa, C. A.; Ensslin, L.; Cornêa, É. C.; Vansnick, J.-C. 1999. Decision support systems in action: integrated application in a multicriteria decision aid process, European Journal of Operational Research 113(2): 315-335.

https://doi.org/10.1016/S0377-2217(98)00219-7

Bana e Costa, C. A.; Nunes da Silva, F.; Vansnick, J.-C. 2001. Conflict dissolution in the public sector: a case-study, European Journal of Operational Research 130(2): 388-401. https://doi.org/10.1016/S0377-2217(00)00037-0

Bana e Costa, C. A.; Oliveira, R. C. 2002. Assigning priorities for maintenance, repair and refurbishment in managing a municipal housing stock, European Journal of Operational Research 138(2): $380-391$.

https://doi.org/10.1016/S0377-2217(01)00253-3

Bana e Costa, C. A.; Oliveira, C. S.; Vieira, V. 2008. Prioritization of bridges and tunnels in earthquake risk mitigation using multicriteria decision analysis: application to Lisbon, Omega 36(3): 442-450. https://doi.org/10.1016/j.omega.2006.05.008

Bana e Costa, C. A.; Vansnick, J.-C. 1999. The MACBETH approach: basic ideas, software, and an application, Mathematical Modelling: Theory and Applications 4: 131-157. https://doi.org/10.1007/978-94-017-0647-6_9

Berry, F.; Gillhespy, S.; Rogers, J. 2018. Airport Sustainability Practices. Airport Cooperative Research Program (ACRP) Synthesis 10. Transportation Research Board (TRB), Washington, DC, US. 112 p. https://doi.org/10.17226/13674 
Bezerra, G. C. L.; Gomes, C. F. 2016a. Measuring airport service quality: A multidimensional approach, Journal of Air Transport Management 53: 85-93.

https://doi.org/10.1016/j.jairtraman.2016.02.001

Bezerra, G. C. L.; Gomes, C. F. 2016b. Performance measurement in airport settings: a systematic literature review, Benchmarking: an International Journal 23(4): 1027-1050.

https://doi.org/10.1108/BIJ-10-2015-0099

Bezerra, G. C. L.; Gomes, C. F. 2018. Performance measurement practices in airports: Multidimensionality and utilization patterns, Journal of Air Transport Management 70: 113-125. https://doi.org/10.1016/j.jairtraman.2018.05.006

Bond, S. 2013. The Importance of Airport Brand - Branding your Airport. Queensland Airports Ltd., Australia. 13 p. Available from Internet: http://www.aci-asiapac.aero/services/main/17/ upload/service/17/self/55cc67ce009f5.pdf

Brunelli, M.; Rezaei, J. 2019. A multiplicative best-worst method for multi-criteria decision making, Operations Research Letters 47(1): 12-15. https://doi.org/10.1016/j.orl.2018.11.008

Burghouwt, G.; De Wit, J.; Veldhuis, J.; Matsumoto, H. 2009. Air network performance and hub competitive position: evaluation of primary airports in East and South-East Asia, Airport Management 3(4): 384-400.

CAG. 2018. Explore Changi. Changi Airport Group (CAG), Singapore. Available from Internet: http://www.changiairport.com/en.html

Cahill, C.; Palcic, D.; Reeves, E. 2017. Commercialisation and airport performance: the case of Ireland's DAA, Journal of Air Transport Management 59: 155-163. https://doi.org/10.1016/j.jairtraman.2016.12.002

Carlucci, F.; Cirà, A.; Coccorese, P. 2018. Measuring and explaining airport efficiency and sustainability: evidence from Italy, Sustainability 10(2): 400. https://doi.org/10.3390/su10020400

Castro, R.; Lohmann, G. 2014. Airport branding: content analysis of vision statements, Research in Transportation Business \& Management 10: 4-14.

https://doi.org/10.1016/j.rtbm.2014.01.001

CDA. 2013. Sustainable Airport Manual. Chicago Department of Aviation (CDA), Chicago, US. 544 p. Available from Internet: https://www.flychicago.com/community/environment/sam/ Pages/default.aspx

Chung, T. W.; Lee, Y. J.; Jang, H. M. 2017. A Comparative analysis of three major transfer airports in Northeast Asia focusing on Incheon international airport using a conjoint analysis, The Asian Journal of Shipping and Logistics 33(4): 237-244. https://doi.org/10.1016/j.ajsl.2017.12.007

Clivillé, V.; Berrah, L.; Mauris, G. 2007. Quantitative expression and aggregation of performance measurements based on the MACBETH multi-criteria method, International Journal of Production Economics 105(1): 171-189.

https://doi.org/10.1016/j.ijpe.2006.03.002

Ennen, D.; Batool, I. 2018. Airport efficiency in Pakistan - a data envelopment analysis with weight restrictions, Journal of Air Transport Management 69: 205-212.

https://doi.org/10.1016/j.jairtraman.2018.02.007

Enoma, A.; Allen, S. 2007. Developing key performance indicators for airport safety and security, Facilities 25(7/8): 296-315. https://doi.org/10.1108/02632770710753334

Eshtaiwi, M.; Badi, I.; Abdulshahed, A.; Erkan, T. 2017. Assessment of airport performance using the grey theory method: a case study in Libya, Grey Systems: Theory and Application 7(3): 426-436. https://doi.org/10.1108/GS-07-2017-0023

Eshtaiwi, M.; Badi, I.; Abdulshahed, A.; Erkan, T. E. 2018. Determination of key performance indicators for measuring air- port success: a case study in Libya, Journal of Air Transport Management 68: 28-34.

https://doi.org/10.1016/j.jairtraman.2017.12.004

Fakhfakh, N.; Verjus, H.; Pourraz, F.; Moreaux, P. 2011. Measuring the Satisfaction Degree of Quality Attributes Requirements for Services Orchestrations, in CTRQ2011: The Fourth International Conference on Communication Theory, Reliability, and Quality of Service, 17-22 April 2011, Budapest, Hungary, 89-94.

Figueiredo, T.; Castro, R. 2019. Passengers perceptions of airport branding strategies: the case of Tom Jobim International Airport - RIOgaleão, Brazil, Journal of Air Transport Management 74: 13-19. https://doi.org/10.1016/j.jairtraman.2018.09.010

Fitch, A. 2016. Iran lays groundwork for regional airport hub in Tehran, The Wall Street Journal 4 October 2016. Available from Internet: https://www.wsj.com/articles/iran-laysgroundwork-for-regional-airport-hub-in-tehran-1475573401

Freathy, P.; O'Connell, F. 1999. Planning for profit: the commercialization of European airports, Long Range Planning 32(6): 587-597. https://doi.org/10.1016/S0024-6301(99)00075-8

Halpern, N.; Pagliari, R. 2008. Direct, moderating and mediating effects of market orientation on the performance of airports in Europe's peripheral areas, Journal of Travel \& Tourism Marketing 24(1): 47-61. https://doi.org/10.1300/J073v24n01_04

Hashemi, S. S.; Razavi Hajiagha, S. H.; Amiri, M. 2014. Decision making with unknown data: development of ELECTRE method based on black numbers, Informatica 25(1): 21-36. https://doi.org/10.15388/Informatica.2014.02

Hashemkhani Zolfani, S.; Chatterjee, P. 2019. Comparative evaluation of sustainable design based on step-wise weight assessment ratio analysis (SWARA) and best worst method (BWM) methods: a perspective on household furnishing materials, Symmetry 11(1): 74. https://doi.org/10.3390/sym11010074

Homsombat, W.; Lei, Z.; Fu, X. 2011. Development status and prospects for aviation hubs - a comparative study of the major airports in South-East Asia, The Singapore Economic Review 56(4): 573-591. https://doi.org/10.1142/S0217590811004420

Hu, J.; Zhang, Y.; Chen, X.; Liu, Y. 2013. Multi-criteria decision making method based on possibility degree of interval type- 2 fuzzy number, Knowledge-Based Systems 43: 21-29. https://doi.org/10.1016/j.knosys.2012.11.007

ICAO. 2013. Airport Economics Manual. International Civil Aviation Organization (ICAO). 152 p. Available from Internet: https://www.icao.int/sustainability/Documents/Doc9562_ en.pdf

ICAO. 2012. Flightpath to a Sustainable Future: the Rio+20 Global Biofuels Initiative. International Civil Aviation Organization (ICAO). 32 p. Available from Internet: https://www.icao. int/environmental-protection/Documents/RIO+20_Flightpath_Review.pdf

Jahangoshai Rezaee, M.; Yousefi, S. 2018. An intelligent decision making approach for identifying and analyzing airport risks, Journal of Air Transport Management 68: 14-27. https://doi.org/10.1016/j.jairtraman.2017.06.013

Jantachalobon, N.; Suthikarnnarunai, N. 2015. The evaluation forms of international passenger airport hub in Southeast Asia, Journal of Applied Engineering Science 13(2): 93-104. https://doi.org/10.5937/jaes13-8382

Karande, P.; Chakraborty, S. 2014. A facility layout selection model using MACBETH method, in Proceedings of the 2014 International Conference on Industrial Engineering and Operations Management, 7-9 January 2014, Bali, Indonesia, 17-26.

Karande, P.; Chakraborty, S. 2013. Using MACBETH method for supplier selection in manufacturing environment, Inter- 
national Journal of Industrial Engineering Computations 4(2): 259-272. https://doi.org/10.5267/j.ijiec.2013.01.002

Keshavarz Ghorabaee, M.; Amiri, M.; Zavadskas, E. K.; Turskis, Z.; Antuchevičienè, J. 2017. A new hybrid simulationbased assignment approach for evaluating airlines with multiple service quality criteria, Journal of Air Transport Management 63: 45-60.

https://doi.org/10.1016/j.jairtraman.2017.05.008

Lai, P.-L.; Potter, A.; Beynon, M.; Beresford, A. 2015. Evaluating the efficiency performance of airports using an integrated AHP/DEA-AR technique, Transport Policy 42: 75-85.

https://doi.org/10.1016/j.tranpol.2015.04.008

Lee, K.; Yu, C. 2018. Assessment of airport service quality: a complementary approach to measure perceived service quality based on Google reviews, Journal of Air Transport Management 71: 28-44.

https://doi.org/10.1016/j.jairtraman.2018.05.004

Lee, Y.-K.; Park, J.-W. 2016. Impact of a sustainable brand on improving business performance of airport enterprises: the case of Incheon international airport, Journal of Air Transport Management 53: 46-53.

https://doi.org/10.1016/j.jairtraman.2016.01.002

Lo Storto, C. L. 2018. The analysis of the cost-revenue production cycle efficiency of the Italian airports: a NSBM DEA approach, Journal of Air Transport Management 72: 77-85. https://doi.org/10.1016/j.jairtraman.2018.05.010

Lozano, S.; Gutiérrez, E.; Moreno, P. 2013. Network DEA approach to airports performance assessment considering undesirable outputs, Applied Mathematical Modelling 37(4): 1665-1676. https://doi.org/10.1016/j.apm.2012.04.041

Milbredt, O.; Castro, A.; Ayazkhani, A.; Christ, T. 2017. Passenger-centric airport management via new terminal interior design concepts, Transportation Research Procedia 27: 12351241. https://doi.org/10.1016/j.trpro.2017.12.008

Mirković, B.; Tošić, V. 2017. The difference between hub and non-hub airports - an airside capacity perspective, Journal of Air Transport Management 62: 121-128.

https://doi.org/10.1016/j.jairtraman.2017.03.013

Monsalud, A.; Ho, D.; Rakas, J. 2015. Greenhouse gas emissions mitigation strategies within the airport sustainability evaluation process, Sustainable Cities and Society 14: 414-424. https://doi.org/10.1016/j.scs.2014.08.003

Montignac, F.; Noirot, I.; Chaudourne, S. 2009. Multi-criteria evaluation of on-board hydrogen storage technologies using the MACBETH approach, International Journal Hydrogen Energy 34(10): 4561-4568.

https://doi.org/10.1016/j.ijhydene.2008.09.098

O'Connell, J. F. 2011. The rise of the Arabian Gulf carriers: an insight into the business model of Emirates airline, Journal of Air Transport Management 17(6): 339-346.

https://doi.org/10.1016/j.jairtraman.2011.02.003

O’Connell, J. F.; Bueno, O. E. 2018. A study into the hub performance Emirates, Etihad Airways and Qatar Airways and their competitive position against the major European hubbing airlines, Journal of Air Transport Management 69: 257-268. https://doi.org/10.1016/j.jairtraman.2016.11.006

OECD. 2001. OECD Environmental Strategy for the First Decade of the 21st Century. Organisation for Economic Cooperation and Development (OECD). 22 p. Available from Internet: https://www.oecd.org/env/indicators-modellingoutlooks/1863539.pdf
Olfat, L.; Amiri, M.; Bamdad Soufi, J.; Pishdar, M. 2016. A dynamic network efficiency measurement of airports performance considering sustainable development concept: A fuzzy dynamic network-DEA approach, Journal of Air Transport Management 57: 272-290.

https://doi.org/10.1016/j.jairtraman.2016.08.007

Olfat, L.; Pishdar, M. 2017. Interval type-2 fuzzy dynamic network data envelopment analysis with undesirable outputs considering double frontiers: an application to Iran airports' sustainability evaluation, International Journal of Industrial Engineering: Theory, Applications and Practice 24(6): 635-662.

Pantouvakis, A.; Renzi, M. F. 2016. Exploring different nationality perceptions of airport service quality, Journal of Air Transport Management 52: 90-98.

https://doi.org/10.1016/j.jairtraman.2015.12.005

Peneda, M. J. A.; Reis, V. D.; Macário, M. do R. M. R. 2011. Critical factors for development of airport cities, Transportation Research Record: Journal of the Transportation Research Board 2214: 1-9. https://doi.org/10.3141/2214-01

Piltz, C.; Voltes-Dorta, A.; Suau-Sanchez, P. 2018. A comparative analysis of hub connections of European and Asian airports against Middle Eastern hubs in intercontinental markets, Journal of Air Transport Management 66: 1-12. https://doi.org/10.1016/j.jairtraman.2017.09.006

Pourhejazy, P.; Sarkis, J.; Zhu, Q. 2019. A fuzzy-based decision aid method for product deletion of fast moving consumer goods, Expert Systems with Applications 119: 272-288. https://doi.org/10.1016/j.eswa.2018.11.001

Puls, R.; Lentz, C. 2018. Retail concessions at European airports: commercial strategies to improve non-aeronautical revenue from leisure travelers, Journal of Air Transport Management 71: 243-249. https://doi.org/10.1016/j.jairtraman.2018.04.010

Rezaei, J. 2015. Best-worst multi-criteria decision-making method, Omega 53: 49-57. https://doi.org/10.1016/j.omega.2014.11.009

Rodgers, B. 2015. Sustainable Airport Master Plan. Master Plan Presentation. University Park Airport, Pennsylvania State University, PA, US. 22 p.

Rodrigues, T. C. 2014. The MACBETH approach to health value measurement: building a population health index in group processes, Procedia Technology 16: 1361-1366. https://doi.org/10.1016/j.protcy.2014.10.153

Roubens, M.; Rusinowska, A.; De Swart, H. 2006. Using MAC$\mathrm{BETH}$ to determine utilities of governments to parties in coalition formation, European Journal of Operational Research 172(2): 588-603. https://doi.org/10.1016/j.ejor.2004.10.017

SAGA. 2018. Sustainable Principles and Practices. Sustainable Aviation Guidance Alliance (SAGA). Available from Internet: http://www.airportsustainability.org

Schmidberger, S.; Bals, L.; Hartmann, E.; Jahns, C. 2009. Ground handling services at European hub airports: Development of a performance measurement system for benchmarking, International Journal of Production Economics 117(1): 104-116. https://doi.org/10.1016/j.ijpe.2008.10.006

Shojaei, P.; Seyed Haeri, S. A.; Mohammadi, S. 2018. Airports evaluation and ranking model using Taguchi loss function, best-worst method and VIKOR technique, Journal of Air Transport Management 68: 4-13.

https://doi.org/10.1016/j.jairtraman.2017.05.006 
Scholz, A. B.; Von Cossel, J. 2011. Assessing the importance of hub airports for cargo carriers and its implications for a sustainable airport management, Research in Transportation Business \& Management 1(1): 62-70.

https://doi.org/10.1016/j.rtbm.2011.06.002

Schulte, S. 2009. Frankfurt strengthens its position as a superhub, International Airport Review 11 December 2009. Available from Internet: https://www.internationalairportreview. com/article/171/frankfurt-strengthens-its-position-as-a-super-hub

Thomas-Emberson, S. 2007. Airport Interiors: Design for Business. John Wiley \& Sons. $232 \mathrm{p}$.

Tłoczyński, D. 2017. Connectivity in air transport networks: an assessment of the Polish aviation market, Research Journal of the University of Gdansk. Transport Economics and Logistics 70: 53-62. https://doi.org/10.5604/01.3001.0010.5922

Wanke, P. F. 2012. Capacity shortfall and efficiency determinants in Brazilian airports: evidence from bootstrapped DEA estimates, Socio-Economic Planning Sciences 46(3): 216-229. https://doi.org/10.1016/j.seps.2012.01.003

Wanke, P.; Barros, C. P.; Nwaogbe, O. R. 2016. Assessing productive efficiency in Nigerian airports using Fuzzy-DEA, Transport Policy 49: 9-19.

https://doi.org/10.1016/j.tranpol.2016.03.012

Wu, D.; Mendel, J. M. 2008. A vector similarity measure for linguistic approximation: interval type- 2 and type- 1 fuzzy sets, Information Sciences 178(2): 381-402.

https://doi.org/10.1016/j.ins.2007.04.014

Wu, D.; Mendel, J. M. 2007. Uncertainty measures for interval type-2 fuzzy sets, Information Sciences 177(23): 5378-5393. https://doi.org/10.1016/j.ins.2007.07.012

Yang, X.; Tok, S. K.; Su, F. 2008. The privatization and commercialization of China's airports, Journal of Air Transport Management 14(5): 243-251.

https://doi.org/10.1016/j.jairtraman.2008.04.012

Zadeh, L. A. 1975. The concept of a linguistic variable and its application to approximate reasoning - I, Information Sciences 8(3): 199-249. https://doi.org/10.1016/0020-0255(75)90036-5 